\title{
FINANCIJSKI UČINCI I UDIO OPĆEG TROŠKA U PROIZVODNJI DRVNIH SORTIMENATA U ŠUMAMA U VLASNIŠTVU RH
}

\author{
FINANCIAL IMPACT AND PROPORTION OF GENERAL \\ EXPENDITURE IN WOOD ASSORTMENTS PRODUCTION \\ IN FORESTS OWNED BY THE REPUBLIC OF CROATIA
}

\section{Branko SITAŠ}

\begin{abstract}
Sažetak
Osnovna svrha ovoga rada je utvrditi strukturu troškova proizvodnje drvnih sortimenata, udio režijskih troškova u proizvodnji drvnih sortimenata, razinu izdvajanja za radove biološke obnove šuma, značajke prihoda od drvnih sortimenata i rezultat po jedinici proizvoda u šumama u vlasništvu Republike Hrvatske. Ukupni financijski pokazatelji prikazat će se jedinično $\left(\mathrm{kn} / \mathrm{m}^{3}\right)$ kako bi podatke mogli učinkovitije uspoređivati i uspješnije koristiti u analitici. $\mathrm{Za}$ potrebe utvrđivanja strukture troškova proizvodnje u državnom poduzeću za gospodarenje šumama Hrvatske šume d.o.o. korišteni su proizvodni, financijski i planski izvještaji koji predstavljaju izvore objektivnih i pouzdanih informacija, oni na razini cijelog poduzeća (društva), kao i navedeni izvještaji za organizacijske jedinice šumarije, uprave šuma podružnice 1-16. U radu su korištene potrebne metode stručnog rada. Za obradu i oblikovanje strukture troškova proizvodnje provedena je empirijska metoda uz primjenu matematičko statističkih obrada.

Istraživanje je pokazalo da u strukturi izravnih troškova proizvodnje izrađenih drvnih sortimenata, zakonom propisani troškovi šumskog doprinosa sudjeluju s $6,2 \%$, zakonom propisana izdvojena sredstva za radove biološke obnove šuma sudjeluju s 5,6\%, osigurana sredstva planom poslovanja Hrvatskih šuma d.o.o. za radove biološke obnove šuma sudjeluju s $29,4 \%$ dok ukupni troškovi radova uzgajanja šuma sudjeluju s $35 \%$ u izravnim troškovima proizvodnje izrađenih drvnih sortimenata. Opći troškovi sudjeluju s 27\% u ukupnim troškovima proizvodnje drvnih sortimenata. Ti odnosi dobar su pokazatelj prilikom ocjenjivanja uspješnosti gospodarenja šumama koje su prirodno bogatstvo i predstavljaju opće dobro Republike Hrvatske.

Zbog buduće bolje učinkovitosti u gospodarenju šumama i postizanja veće financijske koristi u radu je prikazan desetogodišnji niz prosječnih ostvarenih cijena drvnih sortimenata.
\end{abstract}

KLJUČNE RIJEČI: struktura troškova proizvodnje, režijski troškovi, biološka obnova šuma

\section{UVOD}

\section{INTRODUCTION}

U cilju objektivnog obračuna troškova proizvodnje drvnih sortimenata svih organizacijskih jedinica morale su se primijeniti jedinstvene računovodstvene metode obračuna za- liha sirovina i materijala, obračuna amortizacije, metode rasporeda općih troškova na organizacijske jedinice. Ujedno, kod međusobnih obračuna proizvodnih usluga unutar Hrvatskih šuma d.o.o. primijenjen je isti postupak određivanja nositelja troška, odnosno nositelja prihoda. Po- 
sebno je važna objektivna procjena poslovnog rezultata radi uspoređivanja rezultata po organizacijskim jedinicama, analize zajedničkog rezultata na razini Hrvatskih šuma d.o.o. te radi određivanja profitabilnosti pojedinih grupa drvnih proizvoda. Za određivanje profitabilnosti proizvodnje drvnih sortimenata također su korišteni objektivni pokazatelji.

Prilikom donošenja poslovnih odluka vezanih za gospodarenje šumama, ova stručna analiza dobra je osnova za trgovačko društvo i njegovo financijsko poslovanje, za održivost šuma i za dobro stanje šumskog kompleksa. Dobra ocjena financijskog rezultata djelatnosti Proizvodnje drvnih sortimenata temelji se na objektivnom prikazivanju i praćenju rashoda i prihoda gospodarenja šumama. Ujedno su dobra osnova za određivanje realnog iznosa troškova gospodarenja šumama na kršu, odnosno za izračun troškova šumarija u gospodarenju šumama na kršu koji se financiraju iz naknade za korištenje općekorisnih funkcija šuma. Zakon o šumama propisuje da gospodarenje šumama na kršu, osim uzgoja obuhvaća i korištenje šuma i šumskih zemljišta te izgradnju i održavanje šumske infrastrukture. Zbog toga je neophodno u rasporedu sredstava naknade za korištenje općekorisnih funkcija šuma, za gospodarenje šumama na kršu koristiti računovodstvene informacije.

U ovom radu bit će prikazani rashodi i prihodi djelatnosti proizvodnje drvnih sortimenata ukupno za Hrvatske šume d.o.o. te po organizacijskim jedinicama Upravama šuma Podružnicama 1-16. Posebno su izdvojeni izravni troškovi, a posebno opći troškovi Direkcije, Uprave šuma Podružnice i šumarije. Također su prikazani rashodi i prihodi djelatnosti proizvodnje drvnih sortimenata na razini šumarije. Važno je istaknutu da su u rashode proizvodnje drvnih sortimenata uvršteni troškovi izgradnje i održavanje šumske infrastrukture. Istovremeno zbog postojećih poslovnih procesa, prihodi prijevoza drvnih sortimenata do stovarišta kupca nisu uvršteni u prihode.

\section{Prihodi i rashodi proizvodnje drvnih sortimenata na} razini Hrvatskih šuma d.o.o. iskazani $\mathbf{k n} / \mathrm{m}^{3}$ drvnih sortimenta - Wood assortments production revenue and expenditure in Hrvatske šume Ltd. shown in $\mathrm{kn} / \mathrm{m}^{3}$

Prihodi i rashodi proizvodnje drvnih sortimenata prate se u knjigovodstvu za sve šumarije i uprave šuma, kao i za Hrvatske šume d.o.o. uz pomoć informatičkog programa FINPIR. Podaci su prikazani u kunama po jedinici realiziranog proizvoda $\left(\mathrm{kn} / \mathrm{m}^{3}\right)$ radi lakše i bolje međusobne usporedbe između organizacijskih jedinica te ocijene i udjela pojedinog troška. U tablici br. 1 prikazani su prihodi, rashodi i dobit proizvodnje drvnih sortimenata po Upravama šuma 1-16 za 2013. godinu i usporedba s 2012. godinom.

A.) Rashodi proizvodnje drvnih sortimenata - Wood assortments production expenditure grupirani su u ne- koliko grupa, a izračunati su na način da se ukupni troškovi proizvodnje korigiraju s povećanjem odnosno smanjenjem zaliha te podijele s prodanim količinama (tablica br. 1, stupac 2)

1. Troškove šumskog doprinosa (čl. 65. Zakona o šumama) iznose $11,31 \mathrm{kn} / \mathrm{m}^{3}$ (tablica br. 1, stupac 3 ). Troškovi šumskog doprinosa plaćaju se u visini $3,5 \%$ od ukupno prodanih količina po cijeni drvnih proizvoda na panju, a u brdsko-planinskim područjima taj postotak je veći i iznosi 5\%. Šumski doprinos plaća se jedinicama lokalne samouprave, a sredstva se mogu koristiti isključivo za komunalnu infrastrukturu. Najveći iznos šumskog doprinosa plaćen je u Upravi šuma Vinkovci u iznosu $22,48 \mathrm{kn} / \mathrm{m}^{3}$, a najmanji $1,65 \mathrm{kn} / \mathrm{m}^{3} \mathrm{u}$ Upravi šuma Split.

2. Izdvojena sredstva (čl. 61. Zakona o šumama), iznose $10,13 \mathrm{kn} / \mathrm{m}^{3}$ (tablica br. 1. stupac 4). Najveći iznos rezerviranja za dio radova biološke obnove šuma iz čl. 28. točke 10. do 15. Zakona o šumama izdvojen je u Upravi šuma Vinkovci u iznosu $17,07 \mathrm{kn} / \mathrm{m} 3$, a najmanje 4,08 $\mathrm{kn} / \mathrm{m}^{3} \mathrm{u}$ Upravi šuma Split.

3. Osigurana sredstva (čl. 61. Zakona o šumama), iznose $53,40 \mathrm{kn} / \mathrm{m}^{3}$ (tablica br. 1. stupac 6). Najveći iznos rezerviranja za dio radova biološke obnove šuma iz čl. 28. točke 1. do 9. Zakona o šumama, izdvojen je u Upravi šuma Vinkovci u iznosu $103,71 \mathrm{kn} / \mathrm{m}^{3}$, a najmanje 8,04 $\mathrm{kn} / \mathrm{m}^{3} \mathrm{u}$ Upravi šuma Senj. Osigurana sredstava namjenski se troše za biološku obnovu šuma i njihovo povećanje učešća u direktnim troškovima za svaku je pohvalu. U odnosu na prethodnu godinu porasla su $62 \%$.

4. Eksterni troškovi proizvodnje drvnih sortimenata (klasa 4 i 7), iznose $93,06 \mathrm{kn} / \mathrm{m}^{3}$ (tablica br. 1. stupac 5).

5. Troškovi internih obračuna djelatnosti Proizvodnje drvnih sortimenata (skupina 52 i skupina 50 bez konta 5006) iznose $52,62 \mathrm{kn} / \mathrm{m}^{3}$ (tablica br. 1. stupac 7).

6. Proizvodni troškovi (klasa 4, 7 i 5) bez troškova šumskog doprinosa i troškova biološke obnove šuma predstavljaju izravne troškove proizvodnje realiziranih drvnih sortimenata (tablica br. 1. stupac 8) koji objedinjuju eksterne troškove proizvodnje i internih troškove proizvodnje. Prosječni izravni trošak proizvodnje realiziranih drvnih sortimenata iznosi 145,68 kn/m³.

7. Proizvodni troškovi (klasa 4,7 i 5) s troškovima šumskog doprinosa i troškovima biološke obnove šuma (tablica br. 1. stupac 9) iznose $220,52 \mathrm{kn} / \mathrm{m}^{3}$. Ovi troškovi su dobar pokazatelj izravnih troškova proizvodnje drvnih sortimenata, ali nisu korisni za međusobnu usporedbu troškova proizvodnje između uprava šuma. Različito učešće prodanih drvnih sortimenata na panju i kraj panja u pojedinim upravama šuma, mijenja prosječni trošak po jedinici proizvoda. 


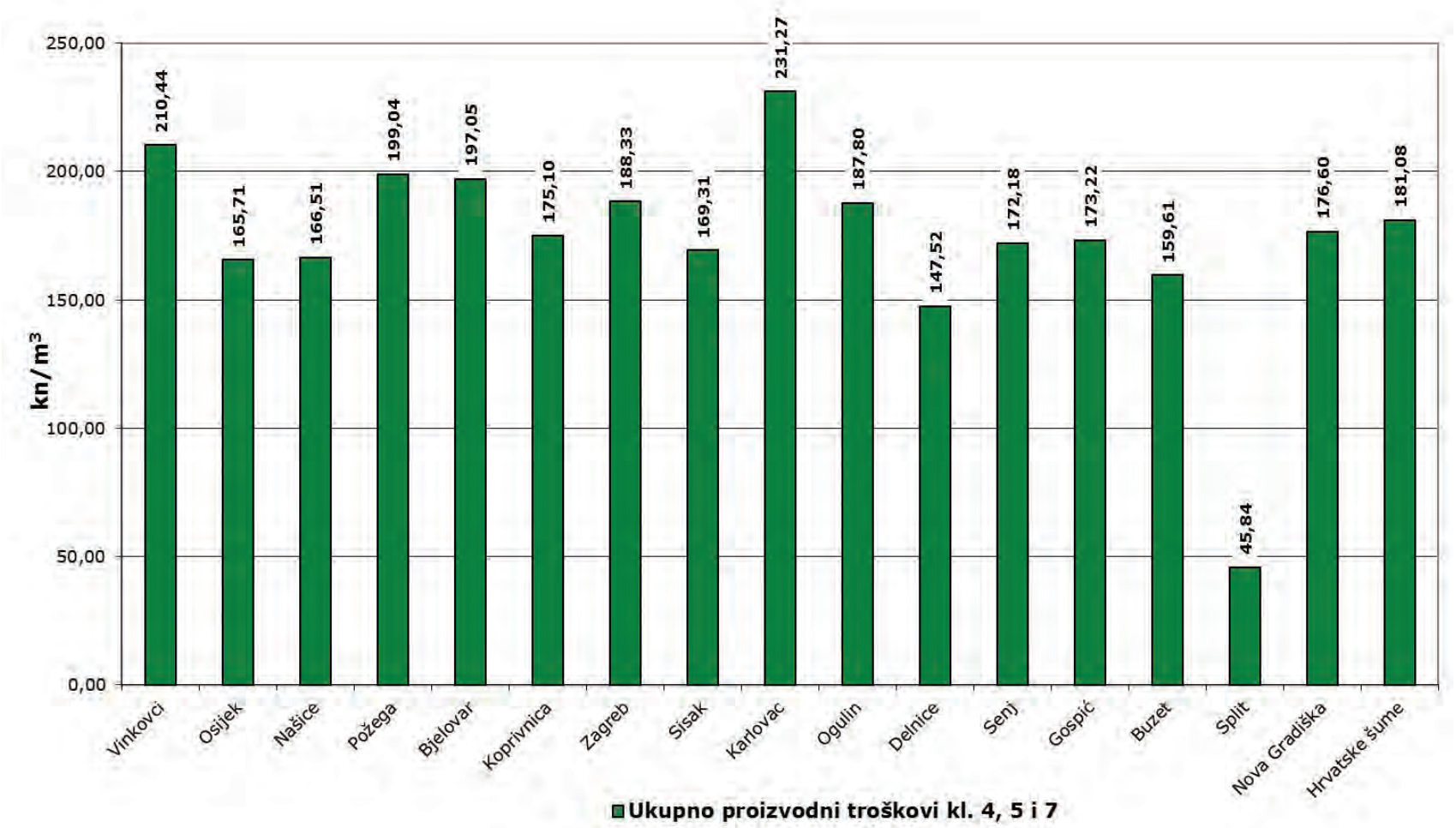

Slika 1.: proizvodni troškovi izrađenih drvnih sortimenata u 2013. godini, bez troškova šumskog doprinosa i troškova biološke obnove šuma $\left(\mathrm{kn} / \mathrm{m}^{3}\right)$ Figure 1: Wood assortments production expenses in 2013 without the costs of forest contribution and biological forest regeneration $\left(\mathrm{kn} / \mathrm{m}^{3}\right)$

8. Proizvodni troškovi izrađenih drvnih sortimenata (klasa 4,7 i 5) bez troškova šumskog doprinosa i troškova biološke obnove šuma daju dobru osnovu za međusobnu usporedbu izravnih troškova proizvodnje izrađenih drvnih sortimenata (tablica br. 1. stupac 14). U izrađene drvne sortimente ne ubrajaju se količine prodane na panju i kraj panja. Prosječni izravan trošak proizvodnje izrađenih drvnih sortimenata iznosi $181,08 \mathrm{kn} / \mathrm{m}^{3}$. Iznos izravnih troškova proizvodnje izrađenih drvnih sortimenata u zavisnosti je od više faktora. Glavni faktori koji utječu na ove troškove su vrsta prihoda odnosno vrsta užite drvne zalihe, srednje kubno stablo, srednja udaljenost privlačenja, otvorenost šuma cestama, tehnologija i organizacija proizvodnje, učinkovitost radne snage. Najniži troškovi proizvodnje izrađenih drvnih sortimenata su u Upravi šuma Split. Ti troškovi nisu za usporedbu, jer ne sadrže osigurana sredstva za radove biološke obnove šuma niti se izvode uobičajeni radovi sječe i izrade. Niže troškove proizvodnje izrađenih drvnih sortimenata od prosjeka Hrvatskih šuma imaju UŠ Delnice 147,52 kn/m³ , UŠ Buzet 159,61 kn/ $\mathrm{m}^{3}$, UŠ Osijek 165,71 kn/m3, UŠ Našice 166,51 kn/m³,

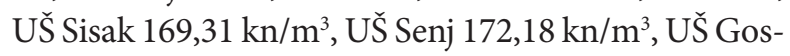
pić $173,22 \mathrm{kn} / \mathrm{m}^{3}$, UŠ Koprivnica $175,10 \mathrm{kn} / \mathrm{m}^{3}$, UŠ Nova Gradiška 176,60 kn/m³ (Slika 1).

U strukturi izravnih troškova proizvodnje izrađenih drvnih sortimenata, zakonom propisani troškovi šumskog doprinosa sudjeluju s 6,2\%, zakonom propisana izdvojena sredstva za radove biološke obnove šuma sudjeluju s 5,6 \%, planom poslovanja Hrvatskih šuma d.o.o. osigurana sredstva za radove biološke obnove šuma sudjeluju s 29,4\%, dok ukupni troškovi radova biološke obnove šuma sudjeluju s $35 \%$.

9. Povećanje odnosno smanjenje vrijednosti zaliha (tablici br. 1, stupac 10 i 11) rezultira povećanjem ili smanjenjem troškove proizvodnje, sukladno računovodstvenim standardima. Povećanje zaliha rezultira smanjenjem troškova proizvodnje, a smanjenje zaliha povećava troškove proizvodnje.

Obračun troškova zaliha obavlja se prema ulaznim računima dobavljača uvećanim za troškove nabave, odnosno za sve troškove dovođenja zaliha na sadašnju lokaciju, a utrošak zaliha vodi se po prosječnim cijenama. Zalihe nedovršene proizvodnje i gotovih proizvoda šumskih sortimenata vrednovane su po neto prodajnoj vrijednosti u skladu s Računovodstvenom politikom MRS-om 2.

10. Ukupni troškovi proizvodnje drvnih sortimenata (tablica br. 1, stupac 12) sadrže sve već nabrojene troškove. Prosječni trošak proizvodnje na razini Hrvatskih šuma d.o.o. s uključenim troškovima šumskog doprinosa, izdvojenim i osiguranim sredstvima za biološku obnovu šuma iznose $219,86 \mathrm{kn} / \mathrm{m}^{3}$. Najviši troškovi proizvodnje su u upravama koje imaju najveće prodajne cijene drvnih sortimenata, jer su troškovi šumskog doprinosa, izdvojenih i osigura- 
Ukupni opći troškovi 2013.

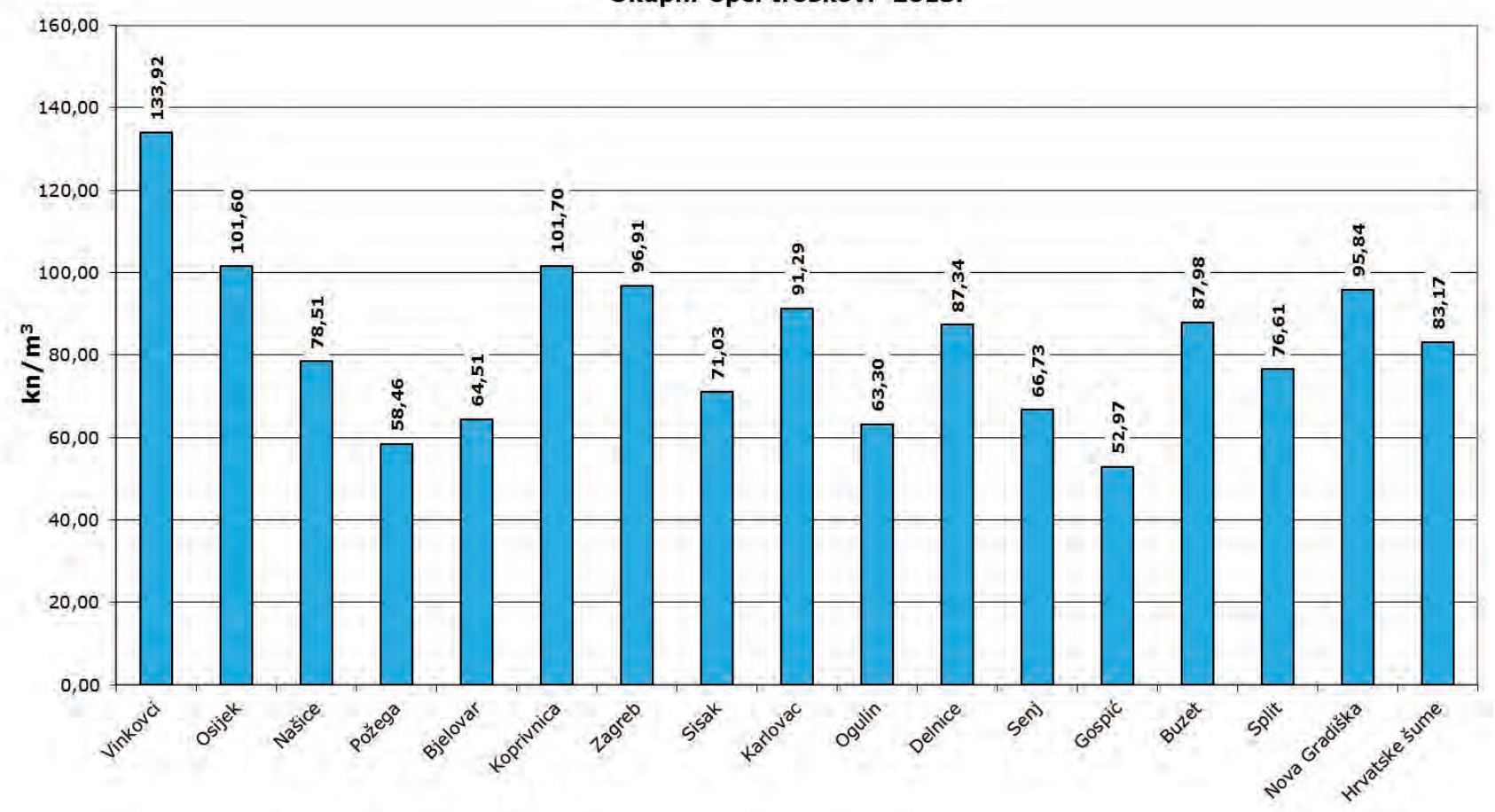

Slika 2.: Ukupni opći troškovi Direkcije, uprave šuma i šumarije raspoređeni po realiziranoj količini drvnih sortimenata u 2013. godini ( $\left.\mathrm{kn} / \mathrm{m}^{3}\right)$ Figure 2: Total general expenses of Management, Forest administration and branch office by realized wood assortments volume in $2013\left(\mathrm{kn} / \mathrm{m}^{3}\right)$

nih sredstava za biološku obnovu šuma proporcionalni prodajnim cijenama drvnih sortimenata.

11. Opći troškovi predstavljaju neizravne troškove koji se ne mogu izravno pratiti po djelatnostima gospodarenja šumama. Te je troškove potrebno odgovarajućim metodama rasporediti na pojedine proizvode koji su uzrokovali njihov nastanak. U postupku alokacije općih troškova proizvodnje na proizvode ti se troškovi prvo identificiraju i prate po mjestima troškova, a budući da se opći troškovi proizvodnje javljaju na tzv. sporednim i pomoćnim mjestima troškova te na glavnim mjestima troškova, potrebno ih je prije njihove alokacije na proizvode alocirati sa sporednih i pomoćnih mjesta troškova na glavna mjesta troškova. Postupak alokacije općih troškova proizvodnje koji nastaju na pomoćnim mjestima troškova na glavna mjesta troškova, napravljen je po algebarskoj (recipročnoj) računovodstvenoj metodi.(1)

11.1. Opći troškovi šumarije (tablica br. 1, stupac 15) sadrže troškove pripadajućeg stručno tehničkog osoblja te ostale neizravne troškove šumarije. Taj trošak kreće se od $18,93 \mathrm{kn} / \mathrm{m}^{3}$ u Upravi šuma Bjelovar do $37,73 \mathrm{kn} /$ $\mathrm{m}^{3} \mathrm{u}$ Upravi šuma Nova Gradiška. Opći troškovi i prihodi šumarije raspoređuju se na djelatnosti gospodarenja šumama u šumariji po načelu udjela rashoda dotične djelatnosti u ukupnim rashodima šumarije.

11.2. Opći troškovi Uprave šuma (tablica br. 1, stupac 16) sadrže troškove pripadajućeg stručno tehničkog osoblja te ostale neizravne troškove uprave šuma. Taj tro- šak kreće se od 20,02 kn/m³ u Upravi šuma Gospić do $78,80 \mathrm{kn} / \mathrm{m}^{3} \mathrm{u}$ Upravi šuma Vinkovci. Opći troškovi i prihodi uprave šuma raspoređuju se na šumarije dotične uprave šuma i djelatnosti gospodarenja šumama po načelu udjela prihoda šumarije u ukupnim prihodima uprave šuma. Na isti način se obračunava raspored općih troškova uprave šuma na djelatnosti gospodarenja šumama.

11.3. Opći troškovi Direkcije (tablica br. 1, stupac 17) sadrže troškove pripadajućeg stručno tehničkog osoblja te ostale neizravne troškove Direkcije. Opći troškova i prihodi Direkcije raspoređuju se na uprave šuma, šumarije i djelatnosti gospodarenja šumama po načelu udjela prihoda uprave šuma u ukupnim prihodima $\mathrm{Hr}$ vatskih šuma d.o.o. Na isti način se obračunava raspored općih troškova i prihoda Direkcije na djelatnosti gospodarenja šumama. Opći troškovi Direkcije kreću se od $8,28 \mathrm{kn} / \mathrm{m}^{3}$ u Upravi šuma Split do $23,99 \mathrm{kn} / \mathrm{m}^{3}$ u Upravi šuma Vinkovci. Uprave s najvećim prihodima snose i najveći udio općih troškova Direkcije.

11.4. Ukupni opći troškovi koji sadrže opće troškove šumarije, uprave šuma i Direkcije (tablica br. 1, stupac 18) kreću se od $64,51 \mathrm{kn} / \mathrm{m}^{3} \mathrm{u}$ Upravi šuma Bjelovar do $133,92 \mathrm{kn} / \mathrm{m}^{3}$ u Upravi šuma Vinkovci. (Slika 2). Na razini Hrvatskih šuma d.o.o. opći troškovi iznose $83,17 \mathrm{kn} / \mathrm{m}^{3}$ što čini $27 \%$ ukupnih troškova proizvodnje drvnih sortimenata. Udio općeg troška proizvodnje u Hrvatskim šumama d.o.o. je sukladan udjelima 


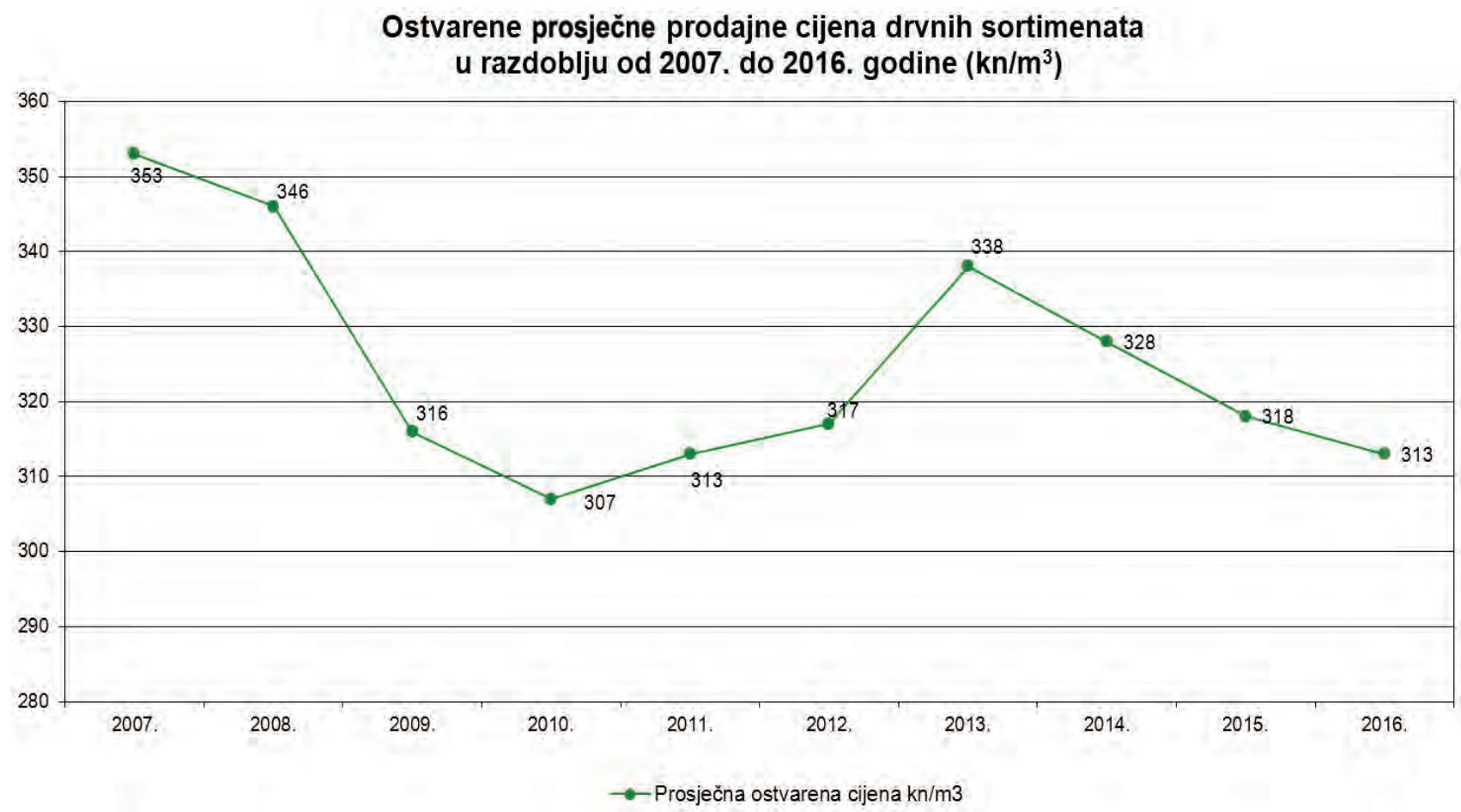

Slika 3.: Ostvarene prosječne cijene drvnih sortimenata u razdoblju od 2007. do 2016. godine Figure 3: Realized average prices of wood assortments in period 2007-2016

općih troškova proizvodnje u većini proizvodnih subjekata u RH. Hrvoje Perčević u znanstvenom radu Metoda obračuna troškova u proizvodnom sektoru Republike Hrvatske navodi:“Za ocjenu tehnološke razvijenosti proizvodnog sektora svakako je najindikativniji udio općih troškova proizvodnje u strukturi ukupnih troškova proizvodnje. Što je njihov udio veći, to se proizvodni sektor može smatrati tehnološki ra- zvijenijim. Prema provedenom istraživanju, u većini proizvodnih subjekata u RH udio općih troškova proizvodnje u strukturi ukupnih troškova proizvodnje iznosi manje od 30\%."(1)

12. Sveukupni rashodi djelatnosti Proizvodnje drvnih sortimenata (tablica br. 1, kolona 19) na razini Hrvatskih šuma d.o.o. iznose $303,03 \mathrm{kn} / \mathrm{m}^{3}$. Najniži sveukupni trošak je $116,37 \mathrm{kn} / \mathrm{m}^{3}$ u Upravi šuma Split, a najviši je

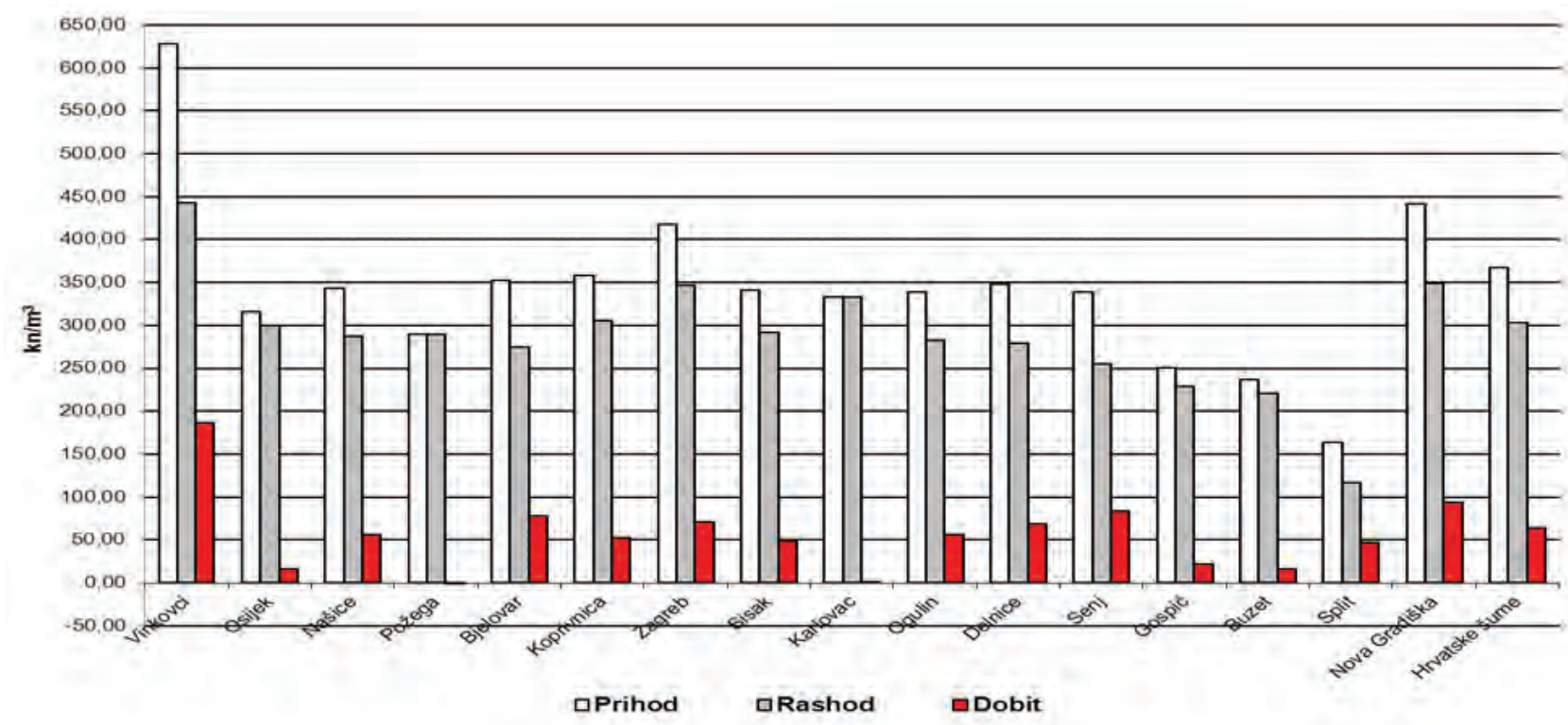

Slika 4.: Prihodi, rashodi i dobit proizvodnje drvnih sortimenata u 2013. godini $\left(\mathrm{kn} / \mathrm{m}^{3}\right)$

Figure 4: Revenue, expenses and profit of wood assortments production in $2013\left(\mathrm{kn} / \mathrm{m}^{3}\right)$ 


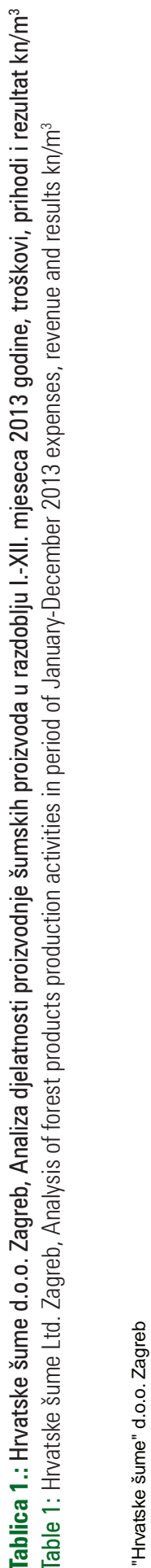

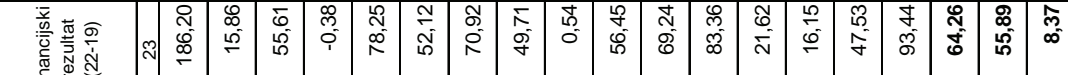

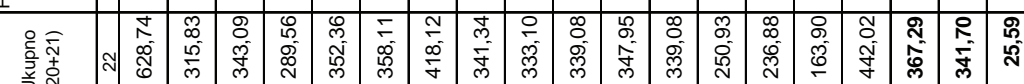

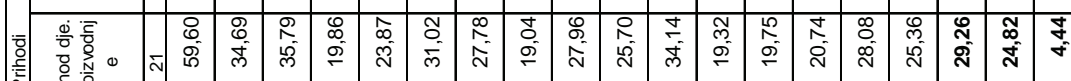
年

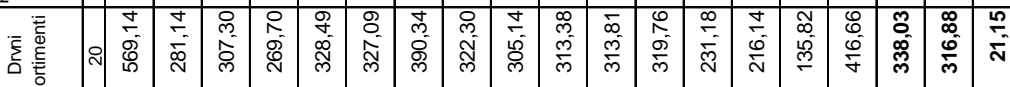

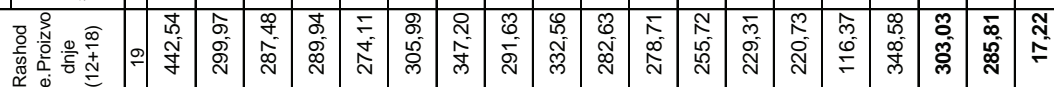

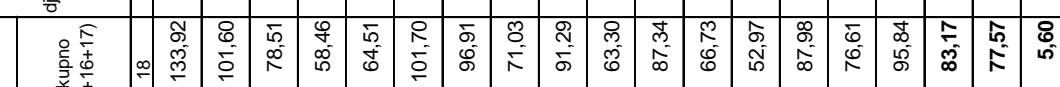

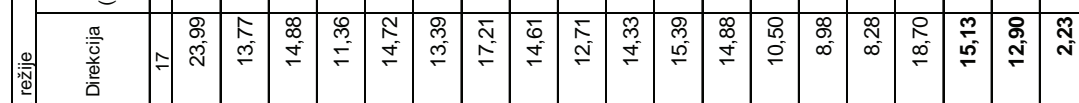

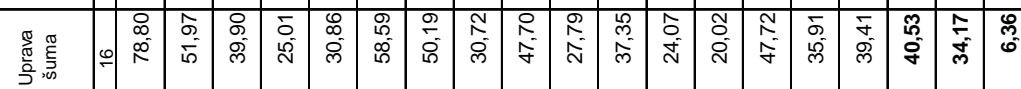

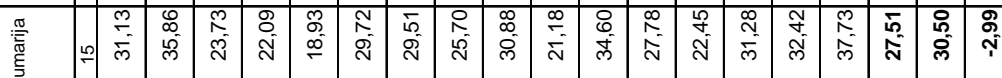

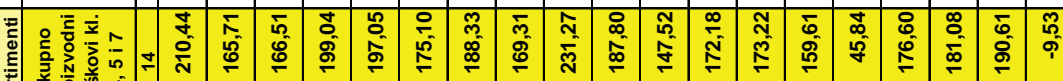

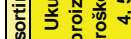

年

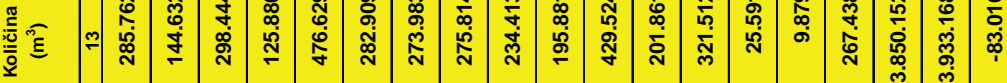

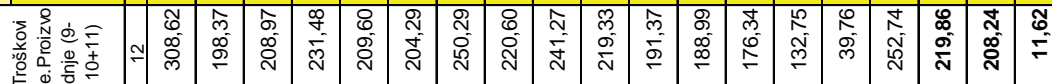

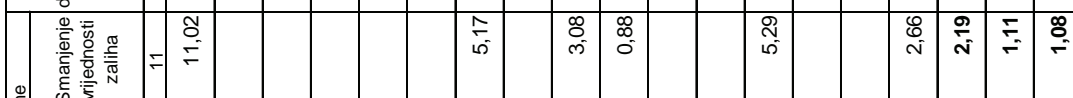

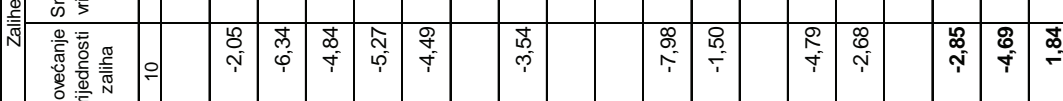

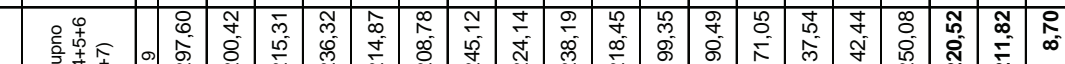

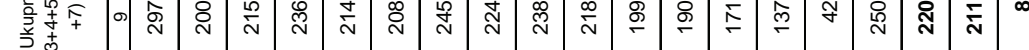

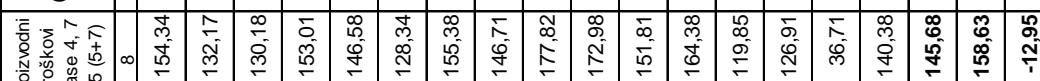

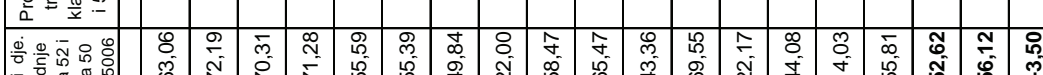

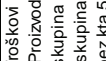

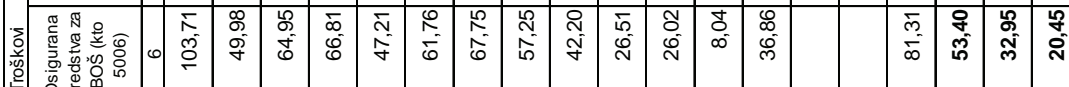

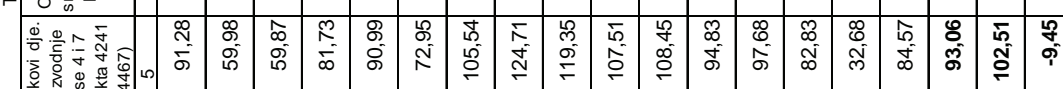

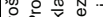

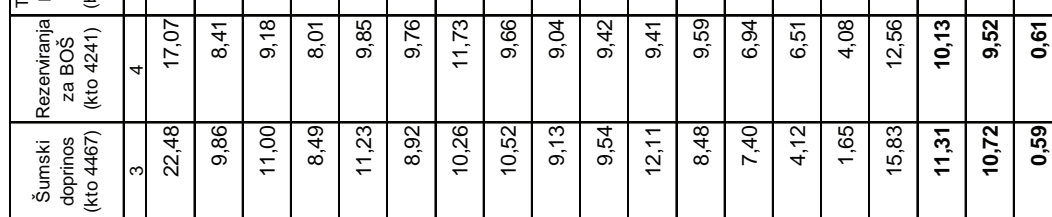

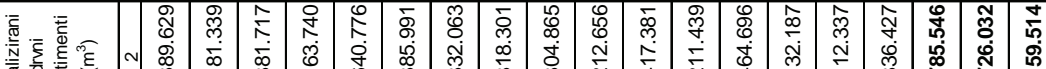

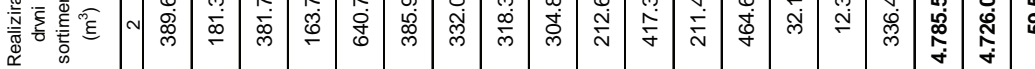

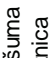

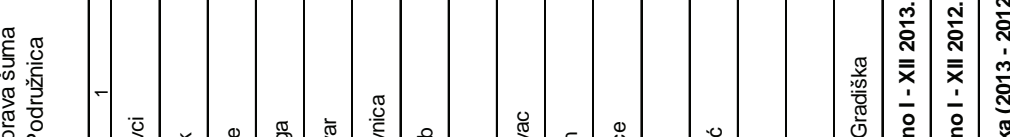

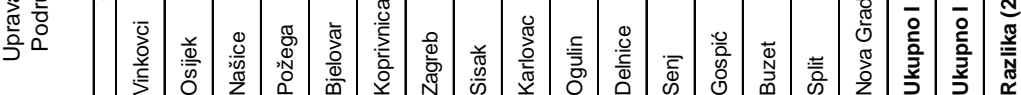


$442,54 \mathrm{kn} / \mathrm{m}^{3}$ u Upravi šuma Vinkovci. Uprava šuma Vinkovci ima opravdano najveće sveukupne troškove proizvodnje drvnih sortimenata. Najveći pripadajući izravni troškovi (šumski doprinos, izdvojena i osigurana sredstva za biološku obnovu šuma) su u zavisnosti s prodajnom cijenom drvnih sortimenata te opsegom i kvalitetom radova biološke obnove šuma. Zbog te činjenice za usporedbu uspješnosti u poslovanju treba koristiti podatke o troškovima izrađenih drvnih sortimenta (kol. 14) koja ne sadrži pripadajuće izravne troškove šumskog doprinosa, izdvojenih i osiguranih sredstava za radove biološke obnove šuma.

B.) Prihodi proizvodnje drvnih sortimenata Wood assortments production revenue grupirani su u dvije grupe

1. Prihodi drvnih sortimenata s ostvarenom prosječnom cijenom $338,03 \mathrm{kn} / \mathrm{m}^{3}$ zahtijevaju dodatnu analitiku s obzirom na tržišnu potražnju i cijene drvnih sortimenta u susjednim zemljama. Iz pregleda ostvarenih cijena drvnih sortimenata vidljivo je da je u 2013. godini ostva- rena najviša cijena u zadnjih pet godina. Ostvarena prosječna cijena drvnih sortimenata u zavisnosti je od više faktora: udjela pojedine vrste drveta, vrsti sječivog prihoda, način prodaje, mjestima prodaje drvnih sortimenata, zastupljenosti određenih sortimenata. U 2013. godini ostvarena je prosječna cijena $519 \mathrm{kn} / \mathrm{m}^{3}$ za oblovinu, $170 \mathrm{kn} / \mathrm{m}^{3}$ za prostorno drvo te prosječna cijena drvnih sortimenata u iznosu $338 \mathrm{kn} / \mathrm{m}^{3}$. Najviša prosječna cijena drvnih sortimenata ostvarena je u Upravi šuma Vinkovci 569,14 kn/ $\mathrm{m}^{3}$ (kol. 20).

2. Ostali prihodi Proizvodnje drvnih sortimenata u koje su uvršteni prihodi od korištenja šumskih cesta, prihodi režije šumarije, Uprave šuma i Direkcije te svi ostali evidentirani prihodi kreću se od $19,04 \mathrm{kn} / \mathrm{m}^{3}$ u Upravi šuma Sisak do 59,6 kn/ $\mathrm{m}^{3}$ u Upravi šuma Vinkovci.

C.) Financijski rezultat proizvodnje drvnih sortimenata Financial results of wood assortments production

U 2013. godini ostvaren je financijski rezultat proizvodnje drvnih sortimenata s dobiti od $64,26 \mathrm{kn} / \mathrm{m}^{3}$. U odnosu na

Tablica 2.: Uprava šuma Podružnica Bjelovar, Analiza proizvodnje šumskih proizvoda za razdoblje I.-XII. mjesec 2013. godine, troškovi, prihodi i rezultat $\mathrm{kn} / \mathrm{m}^{3}$

Table 2: Forest administration branch office Bjelovar, Analysis of forest products production activities in period of January-December 2013 by forest administration branch offices, expenses, revenue and results $\mathrm{kn} / \mathrm{m}^{3}$

Uprava šuma Podružnica Bjelovar

ANALIZA DJ ELATNOSTI PROIZVODNJ E ŠUMSKI H PROIZVODA ZA RAZDOBLJ E I. - XII. MJ ESEC 2013. GODI NE troškovi, prihodi i rezultat po $\mathrm{kn} / \mathrm{m}^{3}$

\begin{tabular}{|c|c|c|c|c|c|c|c|}
\hline & \multicolumn{2}{|c|}{ PLAN } & \multicolumn{2}{|c|}{ IZVRŠENJE } & \multicolumn{2}{|c|}{ Indeks (izv/plan) } \\
\hline & & Iznos (kuna) & $\mathrm{kn} / \mathrm{m}^{3}$ & Iznos (kuna) & $\mathrm{kn} / \mathrm{m}^{3}$ & $\begin{array}{l}\text { Iznos } \\
\text { (kuna) }\end{array}$ & $\mathrm{kn} / \mathrm{m}^{3}$ \\
\hline & 1 & 2 & 3 & 4 & 5 & 6 & 7 \\
\hline \multicolumn{2}{|l|}{ Realizacija $\left(\mathrm{m}^{3}\right)$} & \multicolumn{2}{|c|}{620.770} & \multicolumn{2}{|c|}{640.776} & \\
\hline \multicolumn{2}{|c|}{ Proizvodnja drvnih sortimenata bez samoizrade $\left(\mathrm{m}^{3}\right)$} & \multicolumn{2}{|c|}{511.724} & \multicolumn{2}{|c|}{476.629} & \multirow[b]{2}{*}{101,2} & \multirow[b]{2}{*}{98,1} \\
\hline \multirow{8}{*}{ Troškovi } & Šumski doprinos (kto 4467) & 7.109 .047 & 11,45 & 7.196 .682 & 11,23 & & \\
\hline & \begin{tabular}{|l} 
Rezerviranja za BOŠ (kto \\
4241 )
\end{tabular} & 6.123 .492 & 9,86 & 6.311 .210 & 9,85 & 103,1 & 99,9 \\
\hline & $\begin{array}{l}\text { Troškovi iskorišćivanja klase } \\
4 \text { i } 7\end{array}$ & 57.394 .754 & 92,46 & 58.301 .534 & 90,99 & 101,6 & 98,4 \\
\hline & $\begin{array}{l}\begin{array}{l}\text { Osigurana sredstva za BOŠ } \\
\text { (kto 5006) }\end{array} \\
\end{array}$ & 32.783 .778 & 52,81 & 30.247 .863 & 47,21 & 92,3 & 89,4 \\
\hline & $\begin{array}{l}\text { Troškovi iskoriščivanja klase } \\
5\end{array}$ & 39.007 .574 & 62,84 & 35.618 .955 & 55,59 & 91,3 & 88,5 \\
\hline & \begin{tabular}{|l|} 
Ukupno proizvodni troškovi \\
(troškovi klase 4,5 i 7) \\
\end{tabular} & 96.402 .328 & 155,29 & 93.920 .489 & 146,57 & 97,4 & 94,4 \\
\hline & $\begin{array}{l}\text { Ukupno proizvodni troškovi } \\
\text { (troškovi klase } 4,5 \text { i } 7 \text { ) za } \\
\text { izrađene drvne sortimente }\end{array}$ & 96.402 .328 & 188,39 & 93.920 .489 & 197,05 & 97,4 & 104,6 \\
\hline & Ukupno troškovi & 142.418 .645 & 229,42 & 137.676 .244 & 214,86 & 96,7 & 93,7 \\
\hline \multirow{2}{*}{ Zaliha } & povećanje vrijednosti zaliha & & & -3.375 .687 & $-5,27$ & & \\
\hline & smanjenje vrijednosti zaliha & & & & & & \\
\hline \multicolumn{2}{|c|}{ Troškovi iskorišćivanja šuma } & 142.418 .645 & 229,42 & 134.300 .557 & 209,60 & 94,3 & 91,4 \\
\hline \multirow{4}{*}{ Raspored režije } & šumarije & 12.674 .782 & 20,42 & 12.132 .839 & 18,93 & 95,7 & 92,7 \\
\hline & uprave šume & 13.596 .237 & 21,90 & 19.771.711 & 30,86 & 145,4 & 140,9 \\
\hline & direkcije & 9.467 .420 & 15,25 & 9.434 .116 & 14,72 & 99,6 & 96,5 \\
\hline & ukupno & 35.738 .439 & 57,57 & 41.338 .666 & 64,51 & 115,7 & 112,1 \\
\hline \multicolumn{2}{|c|}{ Rashod iskorišćivanja šuma } & 178.157 .084 & 286,99 & 175.639 .223 & 274,11 & 98,6 & 95,5 \\
\hline \multicolumn{2}{|l|}{ REALIZACIJA } & 204.116 .401 & 328,81 & 210.488 .370 & 328,49 & 103,1 & 99,9 \\
\hline \multicolumn{2}{|c|}{ OSTALI RASP. PRIHODI ISKORIŠĆIVANJ A ŠUMA } & 6.014 .947 & 9,69 & 15.297 .806 & 23,87 & 254,3 & 246,3 \\
\hline \multicolumn{2}{|c|}{ PRIHOD ISKORIŚĆIVANJA ŠUMA } & 210.131 .348 & 338,50 & 225.786 .176 & 352,36 & 107,5 & 104,1 \\
\hline \multicolumn{2}{|c|}{ DOBIT (PRIHOD - RASHOD) } & 31.974 .264 & 51,51 & 50.146 .953 & 78,25 & 156,8 & 151,9 \\
\hline
\end{tabular}

Troškovi klase 5 umanjeni su za osigurana sredstva za BOŚ (konto 5006)!

Troškovi klase 4 i 7 umanjeni su za konto 4467 i 4241

${ }^{*}$ Samoizrada predstavlja izradu drvnih sortimenata kraj panja, za potrebe lokalnog stanovništva.

Najvećim dijelom radi se o izradi ogrjevnog drveta 


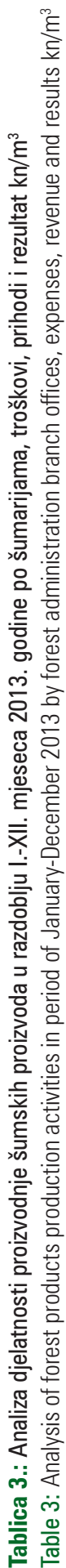

\begin{tabular}{|c|c|c|c|c|c|c|c|c|c|c|c|c|c|c|c|}
\hline 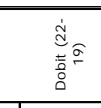 & & 初司 & \begin{tabular}{l|l} 
\\
$:$
\end{tabular} & 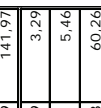 & 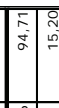 & & & 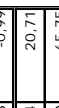 & $\frac{6}{6}$ & $\tilde{\Xi}$ & & 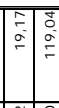 & & & \\
\hline 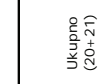 & 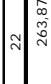 & 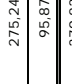 & 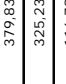 & 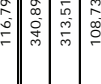 & 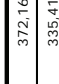 & 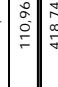 & 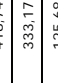 & \begin{tabular}{l}
0 \\
\hdashline
\end{tabular} & $\tilde{m}_{n \rightarrow \infty}^{\infty}$ & $\frac{\tilde{y}}{4}$ & : & 䓵 & 资 & & \\
\hline & $=7$ & 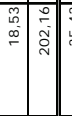 & & \begin{tabular}{c}
$:$ \\
\hdashline
\end{tabular} & 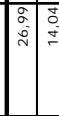 & $\tilde{\Omega}]$ & & 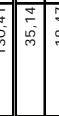 & & & & 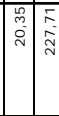 & 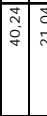 & & \\
\hline & $\approx$ & 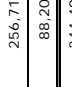 & 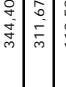 & 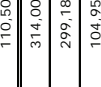 & $\| \overrightarrow{0}$ & 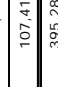 & & & 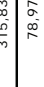 & & \begin{tabular}{l}
7 \\
\multirow{2}{*}{}
\end{tabular} & 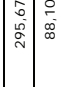 & $\mid$ & & \\
\hline 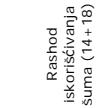 & $1 \%$ & & 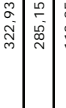 & 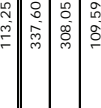 & & 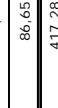 & 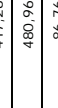 & & 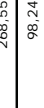 & & 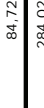 & $\mid$ & & & \\
\hline
\end{tabular}

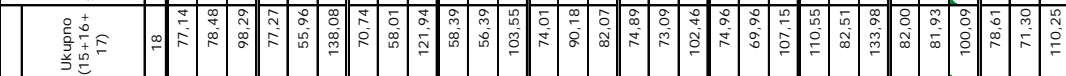

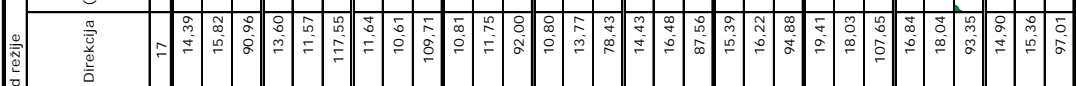

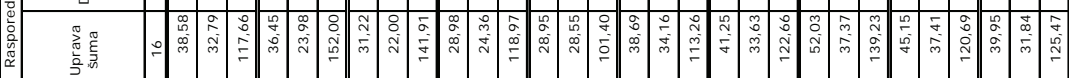

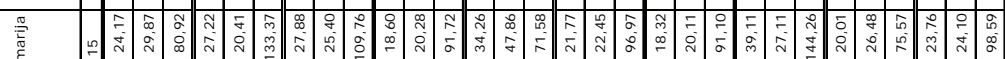

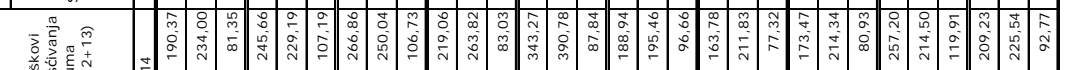

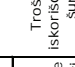

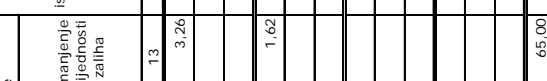

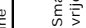<smiles>C1=CC2C=C12</smiles>
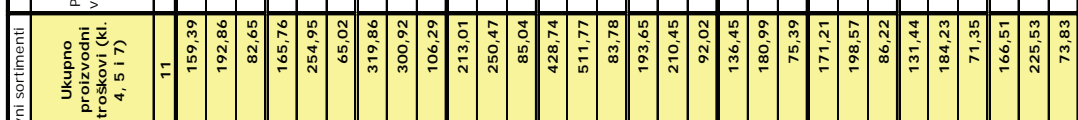

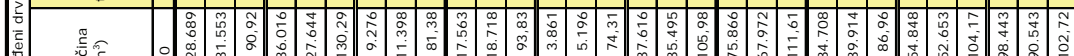

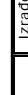

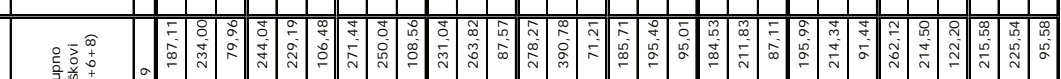

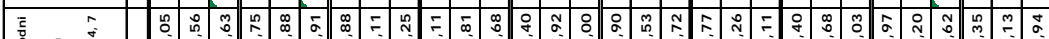

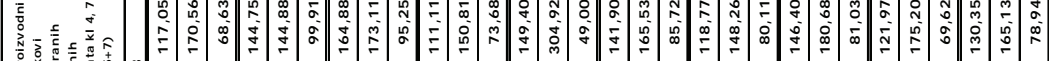

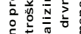

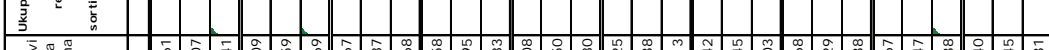

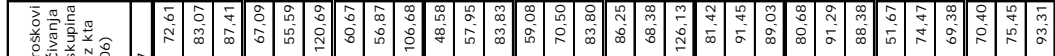

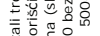

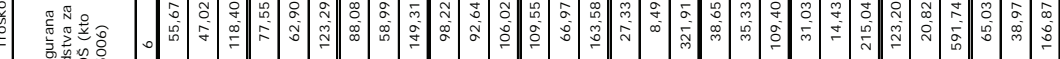

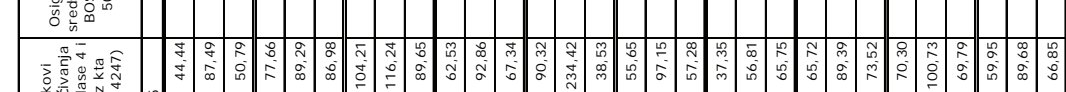

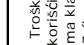

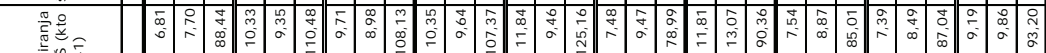
$\sqrt{2}$

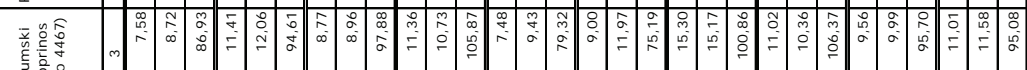

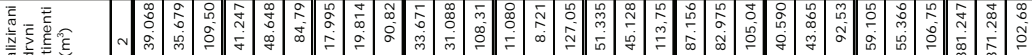

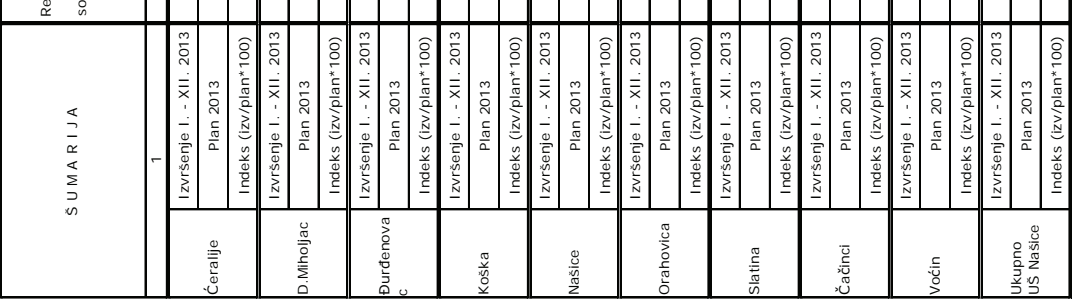


prethodnu godinu rezultat je bolji za $8 \%$. Najbolji financijski rezultat ostvaren je u Upravi šuma Vinkovci 186,20 kn/ $\mathrm{m}^{3}$, Upravi šuma Nova Gradiška $93,44 \mathrm{kn} / \mathrm{m}^{3}$, Upravi šuma Senj $83,36 \mathrm{kn} / \mathrm{m}^{3}$.

\section{Obračun prihoda i rashoda proizvodnje drvnih sortimenata na razini Uprave šuma - Wood assortments production revenue and expenditure statement at Forest administration level}

U tablici br. 2 prikazan je obračun prihoda i rashoda proizvodnje drvnih sortimenata u Upravi šuma Bjelovar koji predstavlja ukupne planirane i ostvarene prihode i rashode djelatnosti Proizvodnje drvnih sortimenata u 2013. godini, ukupne realizirane drvne sortimente, ukupnu proizvodnju drvnih sortimenata umanjene za prodaju na panju i proizvodnju u samoizradi ${ }^{*}$. Svi ti elementi osnova su za naprijed prikazani, obračun prihoda i rashoda proizvodnje drvnih sortimenata po jedinici proizvoda $\left(\mathrm{kn} / \mathrm{m}^{3}\right)$ na razini Hrvatskih šuma d.o.o.

\section{Obračun prihoda i rashoda proizvodnje drvnih sortimenata na razini šumarije - Wood assortments production revenue and expenditure statement at Forest administration branch level}

U tablici 3 prikazan su prihodi, rashodi i financijski rezultat proizvodnje drvnih sortimenata na razini šumarija u Upravi šuma Našice u 2013. godini. Ostvareni rezultati mogu se usporediti s planiranim vrijednostima.

\section{Obračun prihoda i rashoda proizvodnje drvnih sortimenata na razini radilišta - Wood assortments production revenue and expenditure statement at Forest work-site level}

Najznačajnija djelatnost u gospodarenju šumama je djelatnost proizvodnje drvnih sortimenata jer obuhvaća preko $60 \%$ sveukupnih prihoda i rashoda gospodarenja šumama. Zbog boljeg planiranja i praćenja izvršenja proizvodnje drvnih sortimenata, predlaže se dodatna aktivnost u smislu praćenja proizvodnje na razini radilišta. Praćenje planiranih i ostvarenih financijskih rezultata proizvodnje drvnih sortimenata na razini radilišta bila bi dobar pokazatelj uspješnosti stručnog šumarskog osoblja u gospodarenju šumama, a samim tim i dobra osnova za nagrađivanje najuspješnijih.

Konačna ocjena dobrog financijskog učinka proizvodnje drvnih sortimenata potvrda su dobrog gospodarenja državnim šumama. „Ujedno, potvrda su vizionarskog stava sveučilišnog profesora Milana Martinovića, istaknutog šumarskog znanstvenika na polju organizacije šumarstva, šumarske politike i ekonomike. Između objavljenih radova značajan je njegov uradak pod naslovom Iskorištavanje državnih šuma u vlastitoj režiji, objavljenim 1923. godine u seriji članaka Šumarskog lista i brošuri tiskanoj iste godine u Ljubljani. Navedena brošura, tiskana prije više od devedeset godina, trebala je pomoći šumarima i nestručnoj javnosti o spoznaji da šumama treba gospodariti na način... radi kojeg se nećemo stidjeti pred svojim potomstvom. Profesor Martinović ukazivao je na kapitalistički način pridobivanja drva koji pogubno djeluje na šume, tijekom ugovorenog dugotrajnog zakupa i prodaje vrijednog drveta na panju. „(2)

\section{ZAKLJUČAK CONCLUSION}

U strukturi direktnih troškova proizvodnje izrađenih drvnih sortimenata, zakonom propisani troškovi šumskog doprinosa sudjeluju s 6,2\%, zakonom propisana izdvojena sredstva za radove biološke obnove šuma sudjeluju s 5,6 \%, planom poslovanja Hrvatskih šuma d.o.o. osigurana sredstva za radove biološke obnove šuma sudjeluju s $29,4 \%$ dok ukupni troškovi biološke obnove šuma sudjeluju s $35 \%$. Opći troškovi sudjeluju s 27\% u ukupnim troškovima proizvodnje drvnih sortimenata. Opći troškovi gospodarenja šumama u okviru su prosjeka većine proizvodnih subjekata $\mathrm{u}$ RH. Financijski rezultat proizvodnje drvnih sortimenata iskazuje dobit na razini Hrvatskih šuma u iznosu $64,26 \mathrm{kn} /$ $\mathrm{m}^{3}$. Najveću dobit ostvaruje Uprava šuma Vinkovci 186,20 $\mathrm{kn} / \mathrm{m}^{3}$, Uprava šuma Nova Gradiška $93,44 \mathrm{kn} / \mathrm{m}^{3}$, Uprava šuma Senj $83,36 \mathrm{kn} / \mathrm{m}^{3}$. Gore spomenuto učešće troškova radova biološke obnove šuma, učešće troškova režije kao i financijski rezultat dobar su pokazatelj u ocjenjivanju uspješnosti gospodarenja šumama, koje su prirodno bogatstvo i predstavljaju opće dobro Republike Hrvatske.

Bolji financijski rezultat u 2013. godini u odnosu na prethodne godine najvećim dijelom uvjetovan je smanjenjem proizvodnih troškova zbog povećanja produktivnosti vlastitih proizvodnih radnika (nove norme na poslovima sječe, izrade i privlačenja drvnih sortimenata), a manjim dijelom zbog povećanih prihoda od drvnih sortimenata.

Iz višegodišnjeg pregleda ostvarenih cijena drvnih sortimenata može se zaključiti da je u zadnjih deset godina došlo do pada cijena što je u suprotnosti s potražnjom za drvnim sortimentima. Formiranjem tržišnih cijena drvnih sortimenata došlo bi do povećanja prihoda, a samim tim do povećanja ekonomske koristi gospodarenja šumama.

Procesi ujednačavanja i snižavanja općih troškova u organizacijskih jedinicama čiji su opći troškovi iznad prosjeka Hrvatskih šuma, također bi doprinijeli povećanju financijskog efekta gospodarenja šumama.

Svi ovi pokazatelji ukazuju da je državno šumarstvo vlastitom režijom tj. obrazovanim stručnjacima u gospodarenju državnim šumama i proizvodnji drvnih sortimenata, kroz zadnjih šezdeset godina unaprijedilo gospodarenje šumama. Ujedno je to potvrda da integralno gospodarenje 
šumama osigurava dovoljno sredstva za kvalitetnu obnovu i zaštitu šuma, za šumski doprinos koji je prihod lokalnih zajednica, za potrajnost prihoda i povećanje drvne zalihe kao i unaprijeđen životni okoliš te sačuvanu bioraznolikost.

ZAHVALA: Svojim znanjem i iskustvom djelatnici Hrvatskih šuma, dr. sc. Nenad Stanišić i Goran Cajzek dipl. ing. šum. pridonijeli su navedenoj analitici i kreiranju izvještaja o prihodima i rashodima proizvodnje drvnih sortimenata.

\section{LITERATURA}

Perčević, H., 2006: Metode obračuna troškova u proizvodnom sektoru Republike Hrvatske. Ekonomski pregled, 57 (9-10): 647-667.

Krpan, A.P.B., 2013: Iz povijesti šumarstva, Akademija šumarskih znanosti, Zagreb, str. 1-17

\section{Summary}

The main purpose of this paper is to establish the structure of wood assortments production expenditure, the participation of overhead expenses in wood assortments production, the level of expenditure for biological forest regeneration works, the wood assortments revenue characteristics, as well as the results per product unit in forests in the ownership of Republic of Croatia. Final financial indicators will be shown per unit (kn/ $\mathrm{m}^{3}$ ) in order to be able to compare and analyze data more efficiently. Good evaluation of financial results of wood assortments production is based on objective presentation and tracking of forest management revenue and expenditure.

In structure of direct wood assortments production expenditure, legally prescribed expenses for forest contribution participate with $6,2 \%$, legally prescribed means for biological forest regeneration works participate with 5,6\%, means from Hrvatske šume d.o.o. management plan budget for forest regeneration works participate with $29,4 \%$, while total expenditure of forest regeneration works participate with $35 \%$. General expenses participate with $27 \%$ in total wood assortments production expenditure. General expenditure of forest management is within numbers of average expenditure of majority production subjects in Republic of Croatia. Financial results of wood assortments production demonstrate profit on the level of Hrvatske šume Ltd. in the amount of $64.26 \mathrm{kn} / \mathrm{m}^{3}$. The greatest profit makes Forest administration branch office Vinkovci at $186.20 \mathrm{kn} / \mathrm{m}^{3}$, Forest administration branch office Nova Gradiška at $93.44 \mathrm{kn} / \mathrm{m}^{3}$, and Forest administration branch office Senj at $83.36 \mathrm{kn} / \mathrm{m}^{3}$. Aforementioned participation of expenditure of biological forest regeneration works, general expenses participation as well as financial results are good indicators in evaluation of forest management efficacy, as forests are natural resources and common goods of Republic of Croatia.

Better financial result in 2013 in comparison with previous years is for the most part achieved by the decrease of production costs owed to increased productivity of forest workers (new norms for felling, bucking and skidding work), and for the smaller part by increased revenue from wood assortments.

From the multiple-year overview of achieved wood assortments prices it can be concluded that there has been a decrease in prices in the last 10 years, which is contrary to the demand of wood assortments. Forming of the market prices of wood assortments would lead to increase of revenue and therefore to increase of economic benefits from forest management.

Processes of unifying and lowering general expenses in organizational units whose general expenses are above Hrvatske šume average would also contribute to the increase of financial effect of forest management.

All the aforementioned indicators show that the state forestry has improved forest management in the past 60 years by using its own resources, i.e. educated experts for state forest management and wood assortments production. At the same time, this confirms that integrated forest management provides plenty resources for quality regeneration and protection of forest, for forest contribution which is the income for local communities, for sustainable income and increase of wood stock as well as for improved living environment and protected biodiversity.

KEY WORDS: structure of production costs, overhead costs, biological forest regeneration 